\title{
Overexpression of Bcl-2 with Herpes Simplex Virus Vectors Protects CNS Neurons against Neurological Insults In Vitro and In Vivo
}

\author{
Matthew S. Lawrence, ${ }^{1}$ Dora Y. Ho, ${ }^{1}$ Guo Hua Sun, ${ }^{2}$ Gary K. Steinberg, ${ }^{2}$ and Robert M. Sapolsky ${ }^{1}$ \\ ${ }^{1}$ Department of Biological Sciences and 'Department of Neurosurgery and Stanford Stroke Center, Stantord University, \\ Stanford, California 94305
}

Previous studies have demonstrated that overexpression of the proto-oncogene bcl-2 can protect neuron and neuron-like cell lines from growth factor deprivation, calcium ionophores, glutamate excitotoxicity, hypoglycemia, free radicals, and lipid peroxidation. To determine whether $\mathrm{Bcl}-2$ exhibits a similar protective effect in CNS neurons, we generated defective herpes simplex virus (HSV) vectors capable of overexpressing $\mathrm{Bcl}-2$ in primary cultures and in the intact brain. Infection of hippocampal cultures with $\mathrm{Bcl}-2$ vectors enhanced neuron survivorship after exposure to adriamycin, a potent oxygen radical generator. Furthermore, dichlorofluorescein measurements indicated that there was a significant reduction in the accumulation of oxygen radicals associated with this insult. $\mathrm{Bcl}-2$ vectors also enhanced survival in cultured neurons after exposure to glutamate and hypoglycemia. Most significantly, the in vivo delivery of the vector protected neurons against adriamycin toxicity in the dorsal horn of the dentate gyrus and focal ischemia in the striatum.

Key words: Bcl-2; herpes simplex virus; gene transfer; adriamycin; glutamate; hypoglycemia; hypoxia-ischemia
The proto-oncogene $b c l-2$, originally isolated from the follicular lymphoma chromosomal translocation $\mathrm{t}(14 ; 18)$ (Bakhshi et al., 1985; Tsujimoto et al., 1985), is a potent inhibitor of certain cell death pathways (Reed, 1994). Consistent with this role, endogenous Bcl-2 expression is largely restricted to long-lived or proliferative tissues (Hockenbery et al., 1991). Experimentally elevated expression of $\mathrm{Bcl}-2$ has been shown to protect hematopoietic, neuronal, and neuron-like cell lines from the programmed cell death induced by trophic factor deprivation (Vaux, 1988; Nunez et al., 1990; Garcia et al., 1992; Allsopp et al., 1993; Mah et al., 1993) and gamma irradiation (Sentman et al., 1991; Strasser et al., 1991). Overexpression of Bcl-2 has also been shown to prevent lipid peroxidation and cell loss in hematopoietic and hypothalamic cell lines after oxidative insults (Hockenbery et al., 1993; Kane et al., 1993) and to block necrotic cell death in conditionally immortalized nigral neurons resulting from exposure to calcium ionophores, glucose withdrawal, membrane peroxidation, free radical formation, and glutamate excitotoxicity (Behl et al., 1993; Zhong et al., 1993). In vivo, the overexpression of Bcl-2 in transgenic mice protects facial motor neurons from axotony-induced death (Dubois-Dauphin et al., 1994) and striatal neurons from focal ischemia (Martinou et al., 1994).

The prevention of neuron death induced by such diverse insults suggests that $\mathrm{Bcl}-2$ intervenes at a physiological step common to both apoptotic and necrotic neuron death pathways, perhaps by the neutralization of reactive oxygen species. This is supported by Bcl-2's ability to suppress lipid peroxidation and protect cells from oxidative damage (Hockenbery et al., 1990, 1993; Kane et al., 1993) and its intercellular localization at sites of free radical

Received June 5, 1995; revised Aug. 14, 1995; accepted Sept. 20, 1995.

Support was provided by a Howard Hughes predoctoral fellowship (M.S.L.), the Adler Foundation (R.M.S.), and National Institutes of Health NINDS Grant RO1 NS27292-01A2 (G.K.S.).

Correspondence should be addressed to Dr. Robert Sapolsky at the above address.

Copyright $(1996$ Society for Neuroscience $0270-6474 / 96 / 160486-11 \$ 05.00 / 0$ generation, including endoplasmic and outer mitochondrial membranes (Lithgow et al., 1994). A broad protective effect arising from such antioxidant properties is consistent with the involvement of oxidative stress in many forms of neuron death. The consequent alteration of calcium homeostasis, lipid peroxidation, and membrane damage is an important component of both glutamate excitotoxicity (Coyle and Puttfarcken, 1993) and the apoptotic death induced by growth factor withdrawal, hyperthermia, radiation, and glucocorticoids (Wood and Youle, 1994).

These findings suggest that $\mathrm{Bcl}-2$ overexpression in the CNS protects against a variety of neurological insults. A significant obstacle to testing such a possibility is the difficulty of gene transfer to postmitotic neurons. Herpes simplex virus (HSV) vectors have been used previously to overexpress genes for tyrosine hydroxylase (During et al., 1994) and the glucose transporter (Lawrence et al., 1995a) to protect against in vitro or rodent models of necrotic and neurodegenerative insults. In the present study, we have used HSV vectors to investigate the neuroprotective properties of $\mathrm{Bcl}-2$ overexpression. Coexpressing the Escherichia coli lacZ marker gene and the human bcl-2 gene (or a truncated dysfunctional gene) allowed the identification of targeted neurons and the quantification of differential survivorship in the face of oxidative, excitotoxic, hypoglycemic, and ischemic insults.

\section{MATERIALS AND METHODS}

Cell culture. Hippocampal tissue was dissected from day 18 fetal SpragueDawley rats, digested with papain $(10 \mathrm{U} / \mathrm{ml})$, and mechanically dispersed by triteration. Cells were plated in 48 well poly-D-lysine-treated culture dishes $\left(1.0 \times 10^{5}\right.$ cells/well $)$ and maintained in $30 \mathrm{mM}$ glucose MEM-PAK (a modified minimum essential medium; University of California San Francisco cell culture facility) supplemented with $10 \%$ horse serum (Hyclone, Logan, UT). E5 cells (DeLuca et al., 1985) used for viral vector generation and Vero (ATCC CCL81) cells used for vector titering and immunofluorescence were maintained in DMEM (Gibco, Grand Island, NY) supplemented with $10 \%$ NuSerum (Collaborative Research, Bedford, MA). All cells were incubated at $37^{\circ} \mathrm{C}$ in $5 \% \mathrm{CO}_{2} / 95 \%$ air. 
Construction of plasmids. A bicistronic expression system was generated as described previously (Lawrence et al., 1995a). Briefly, the plasmid p $\alpha 22 \beta$ gal $\alpha 4 b c l-2$ was constructed containing the $b c l-2$ and $l a c Z$ genes under the control of HSV $\alpha 4$ and $\alpha 22$ promoters, respectively, with HSV or $i_{\mathrm{s}}$ and $a$ sequences included to provide the necessary replication and packaging signals. A 1920 bp $X b a \mathrm{I}-E c o$ RI fragment containing the $b c l-2$ coding sequences and a poly(A) signal from the plasmid pDVbcl-2 [provided by David Vaux (Vaux et al., 1992)] was inserted downstream of the $\alpha 4$ promoter. This placed the $b c l-2$ and $l a c Z$ transcriptional units under the control of the HSV $\alpha 4$ and $\alpha 22$ immediate early promoters, respectively. The control plasmid p $\alpha 22 \beta$ gal $\alpha 4$ bst was constructed by the removal of a $560 \mathrm{bp}$ PstI fragment encompassing codons $220-780$ in the $b c l-2$ sequence and the further insertion of a linker containing termination codons in all three reading frames.

Generation of viral vectors. Vectors wcrc gencratcd by transfection of plasmids into E5 cells using lipofectamine (Gibco) and superinfecting 24 $\mathrm{hr}$ later with the helper virus d120 at a multiplicity of infection (MOI) of 0.3 (Ho, 1994). d120 has a deletion mutation in the $\alpha 4$ gene, requiring propagation in E5 cells, which have been stably transformed with $\alpha 4$ (DeLuca et al., 1985). Superinfection gave rise to vector titers of $2-3 \times$ $10^{6}$ infectious particles/ml and $\mathrm{d} 120$ helper virus titers of $0.4-1.0 \times 10^{7}$ plaque-forming units (PFU)/ml. For in vivo microinfusion, viral vectors were concentrated 5- to 10-fold using microconcentrator devices with $M_{\mathrm{r}}$ cutoff of $100 \mathrm{kDa}$ (Amicon, Beverly, MA).

In vitro immunofluorescence. Vero cells were grown to $70 \%$ confluency overnight on glass coverslips and mock-infected or infected with either v $\alpha 22 \beta$ gal $\alpha 4$ bcl -2 or $v \alpha 22 \beta$ gal $\alpha 4$ bst $($ MOI $\sim 0.3$ ). Eight hours later, cells were fixed in acetone/methanol $(3: 1)$. Cells were then labeled with anti$\beta$-galactosidase ( $\beta$-gal) rabbit serum $(1: 100$; Vector Laboratories, Burlingame, $\mathrm{CA})$ and anti-Bcl-2 mouse antibody (1:50; Daco, Carpinteria, $\mathrm{CA}$ ), followed by goat anti-rabbit antibody conjugated to rhodamine $(1: 100 ;$ Vector) and goat anti-mouse antibody conjugated to fluorescein ( $1: 20 ;$ Vector). The total number of $\mathrm{Bcl}-2$ and $\beta$-gal ${ }^{+}$cells were counted at $40 \times$ magnification in 10 randomly selected cell fields in v $\alpha 22 \beta$ gal $\alpha 4 \mathrm{bcl}-$ 2 -infected Vero cultures to provide an estimate of the percentage of cells that coexpressed the two gene products and, hence, a measure of the relative efficiencies of gene expression under the two promoters.

In vivo immunofluorescence. To evaluate in vivo coexpression of the $b c l-2$ and $l a c Z$ genes, an animal received a hippocampal microinfusion of v $\alpha 22 \beta$ gal $\alpha 4 \mathrm{bcl}-2$ into the right hemisphere and $v \alpha 22 \beta$ gal $\alpha 4 \mathrm{bst}$ into the left hemisphere. The animal was killed $24 \mathrm{hr}$ later, the brain was frozen in 2-methylbutane $\left(-20^{\circ} \mathrm{C}\right)$, and $5 \mu \mathrm{m}$ coronal sections were taken at the site of injection. Sections were then labeled as described previously with anti- $\beta$-gal rabbit serum (1:20) and anti-Bcl-2 mouse serum (1:100), followed by goat anti-rabbit antibody conjugated to rhodamine $(1: 100)$ and goat anti-mouse antibody conjugated to fluorescein $(1: 20)$.

Cell treatments. On day 10 when cultures were $\sim 50: 50$, neurons/astrocytes [as assessed by immunostaining with a mouse monoclonal antibody against microtubule-associated protein 2 (MAP2) (1:1000 dilution; Sigma, St. Louis, MO) and glial fibrillary acidic protein (GFAP), using the Vectastain ABC kit for peroxidase (Vector) (Tombaugh et al., 1992)], wells were infected with $5 \mu \mathrm{l}$ of v $\alpha 22 \beta \mathrm{gal} \alpha 4 \mathrm{bcl}-2$ or $\mathrm{v} \alpha 22 \beta \mathrm{gal} \alpha 4 \mathrm{bst}$ (vector titer diluted to $1.0 \times 10^{5}$ infectious particles $/ \mathrm{ml}$ and a helper virus titer of $5.0 \times 10^{5} \mathrm{PFU} / \mathrm{ml}$, yielding an MOI of 0.005 and 0.025 , respectively; in all experiments the titer of vector and helper virus of the $\mathrm{Bcl}-2$ and control viral stocks were matched as closely as possible). Six hours later, cultures were subjected to experimental manipulations. Those subjected to a pro-oxidative insult received $0,0.1,0.3,0.9,2.7,8.1$, and $24.3 \mu \mathrm{M}$ adriamycin (doxorubicin hydrochloride; Sigma) in DMEM. Twenty-four hours later, cells were fixed in $0.5 \%$ gluteraldehyde and stained with 5 -bromo-4-chloro-3-indolyl- $\beta$-D-galactopyranoside (X-gal; Molecular Probes, Eugene, OR). Another series of cultures was subjected to $0.9 \mu \mathrm{M}$ adriamycin for $0,8,16,24,32,40$, or $48 \mathrm{hr}$ before staining. In vitro glutamate toxicity exhibits an acute osmotic component that arises from the opening of glutamate-gated ion channels and a delayed NMDA component arising from the activation of kinases, phospholipases, and the generation of oxygen radicals (Hockenbery et al., 1993). Thus, to address the second delayed component of the excitotoxic insult, those cultures subjected to a glutamate insult were washed in an osmotically neutral $\mathrm{Cl}^{-}$-free DMEM (Ho et al., 1995) $6 \mathrm{hr}$ after viral infection and exposed to $\mathrm{Cl}^{-}$-free DMEM with $0,25,50,75,100$, and $200 \mu \mathrm{M}$ glutamate (Sigma) for $30 \mathrm{~min}$, after which cells were washed and maintained in 5 mM glucose DMEM for $24 \mathrm{hr}$ before fixing. Those cultures subjected to glucose manipulations were washed with $0.2 \mathrm{~mm}$ glucose DMEM and exposed to 0.2 or $5 \mathrm{~mm}$ glucose DMEM for $24 \mathrm{hr}$ before fixation.
Cell counts. $\beta$-gal ${ }^{+}$cells exhibiting neuronal morphologies with intact healthy processes were counted by an investigator blind to the experimental manipulations, and the mean values for v $\alpha 22 \beta \mathrm{gal} \alpha 4 \mathrm{bcl}-2-$ and $v \alpha 22 \beta$ gal $\alpha 4$ bst-infected wells for each treatment group were expressed as a percent of $\beta$-gal ${ }^{+}$neurons counted in corresponding infected wells not subjected to adriamycin, glutamate, or hypoglycemia. Comparisons of neuronal survivorship between treatment groups at each dose or time point were made by ANOVA. In the calculation of median lethal dose and median lethal time, data were linearized by logarithmic transformation, and a linear regression was performed on each treatment group.

Assessment of peroxidative damage. The compound $2^{\prime}, 7^{\prime}$ dichlorofluorescein diacetate (DCFH-DA) has been used to identify oxidative stress in living cells (Lebel et al., 1990; Rosenkranz et al., 1992). Intercellular esterases cleave the diacetate, resulting in nonfluorescent dichlorofluoresecin (DCFH) that remains within the cell. In the presence of peroxides, DCFH is oxidized to become fluorescent dichlorofluorescein (DCF), the emissions of which can be measured at $538 \mathrm{~nm}$ upon excitation at $488 \mathrm{~nm}$. To quantify the intracellular accumulation of reactive oxygen species in hippocampal cultures, cells were plated in 96 well poly-D-lysine-treated culture dishes $\left(6.0 \times 10^{4}\right.$ cells/well in $200 \mu \mathrm{l}$ of $30 \mathrm{~mm}$ glucose MEM-PAK with $10 \%$ horse serum). On day 8 , cultures were infected with $15 \mu \mathrm{l} /$ well v $\alpha 22 \beta$ gal $\alpha 4$ bcl- 2 or v $\alpha 22 \beta$ gal $\alpha 4$ bst (vector titer of $2.0 \times 10^{6}$ infectious particles $/ \mathrm{ml}$ and a helper virus titer of $1.0 \times$ $10^{7} \mathrm{PFU} / \mathrm{ml}$ ) or were mock-infected. Eight hours later, media were replaced with $1 \mu \mathrm{M}$ adriamycin in DMEM $(200 \mu \mathrm{l} / \mathrm{well}), 20 \mathrm{hr}$ after which wells were washed twice with a modified Krebs-Ringer (KR) solution (Kane et al., 1993). KR buffer containing DCFH-DA $(1 \mu \mathrm{g} / \mathrm{ml}$ in $100 \mu \mathrm{l}$; Molecular Probes) was then added, and fluorescence was measured after 15 min using an ICN Titertek Fluoroskan II microfluorometry plate reader. DCF fluorescence was expressed as a percent of fluorescence values obtained in uninfected control wells that had not been treated with adriamycin, and differences between treatments were compared by ANOVA.

In vivo adriamycin studies. Adult male Sprague-Dawley rats (250-300 $\mathrm{gm}$ ) were microinfused bilaterally with $2 \mu \mathrm{l}$ of either $v \alpha 22 \beta \mathrm{gal} \alpha 4 \mathrm{bcl}-2$ or v $\alpha 22 \beta \mathrm{gal} \alpha 4 \mathrm{bst}$ (vector titer of $5 \times 10^{6}$ infectious particles $/ \mathrm{ml}$ and helper virus titer of $1-2 \times 10^{7} \mathrm{PFU} / \mathrm{ml}$, at stereotaxic coordinates from lambda: AP 4.1, ML 2.0, DV 3.0). Microinfusions were made through implanted cannulae such that vector could be delivered either $12 \mathrm{hr}$ before or simultaneous with the unilatcral delivery of $1 \mu \mathrm{l}$ of adriamycin $(2 \mathrm{~mm})$ at the same site. Animals were killed $48 \mathrm{hr}$ after adriamycin administration and perfused with heparinized saline and $2 \% p$-formaldehyde, and brains were removed and postfixed ( $2 \% p$-formaldehyde, $20 \%$ sucrose) for $2 \mathrm{~d}$ before sectioning. Coronal sections $(25 \mu \mathrm{m})$ were collected every $100 \mu \mathrm{m}$ for $800-1000 \mu \mathrm{m}$ anterior and posterior to the infusion site. Sections were immersed in an X-gal solution for $6 \mathrm{hr}$ before cresyl-violet staining. The total number of intact $\beta$-gal ${ }^{+}$dentate neurons were counted in successive sections in the adriamycin-treated hemisphere and cxpressed as a percent of the number of $\beta$-gal ${ }^{+}$neurons counted in the contralateral control hemisphere to arrive at a measure of survivorship. Statistical comparisons between groups were made by ANOVA. The extent of adriamycininduced damage was quantified by measuring the length and width of the lesion in the dentate with a calibrated ocular grid at $40 \times$ magnification. Areas of damage within successive sections were then integrated into a measure of total volume of damage. Given the limited number of neurons that could be targeted to overexpress $\mathrm{Bcl}-2$, it was not expected that there would be an overall reduction in lesion size in $v \alpha 22 \beta \mathrm{gal} \alpha 4 \mathrm{bcl}-2$ infected and control animals. To confirm that this was the case and that any differential survival observed was not a result of differential damage endured, the total damage between v $\alpha 22 \beta \mathrm{gal} \alpha 4 \mathrm{bcl}-2-$ and $v \alpha 22 \beta$ gal $\alpha 4$ bst-infused animals was compared by an unpaired Student's $t$ test.

Middle cerebral artery occlusion studies. Sprague-Dawley rats (300-350 $\mathrm{gm})$ received bilateral striatal infusions of either $v \alpha 22 \beta \mathrm{gal} \alpha 4 \mathrm{bcl}-2$ or v $\alpha 22 \beta \mathrm{gal} \alpha 4 \mathrm{bst}$ (vector titcr of $1 \times 10^{7} \mathrm{infcctious}$ particles $/ \mathrm{ml}$ and helper virus titer of $1-5 \times 10^{7} \mathrm{PFU} / \mathrm{ml}$, at stereotaxic coordinates from bregma: AP 0, ML 3.5, with 2 injection sites of $3 \mu$ l each at DV 4.5 and $3.5 \mathrm{~mm}$ ). Six hours later, the left middle cerebral artery was occluded for $1 \mathrm{hr}$ by the insertion of an intraluminal 30 gauge nylon suture through the common carotid artery to the branch point of the middle cerebral artery and the anterior cerebral artery (Longa et al., 1989; Memezawa et al., 1992; Yoon and Steinberg, 1994). Animals were killed 48 hr later, brain sections were prepared as described previously, and the number of $\beta$-gal ${ }^{+}$neurons were counted at $40 \times$ magnification in successive sections in each hemisphere The total number of $\beta$-gal ${ }^{+}$neurons in the occluded hemisphere were 
A

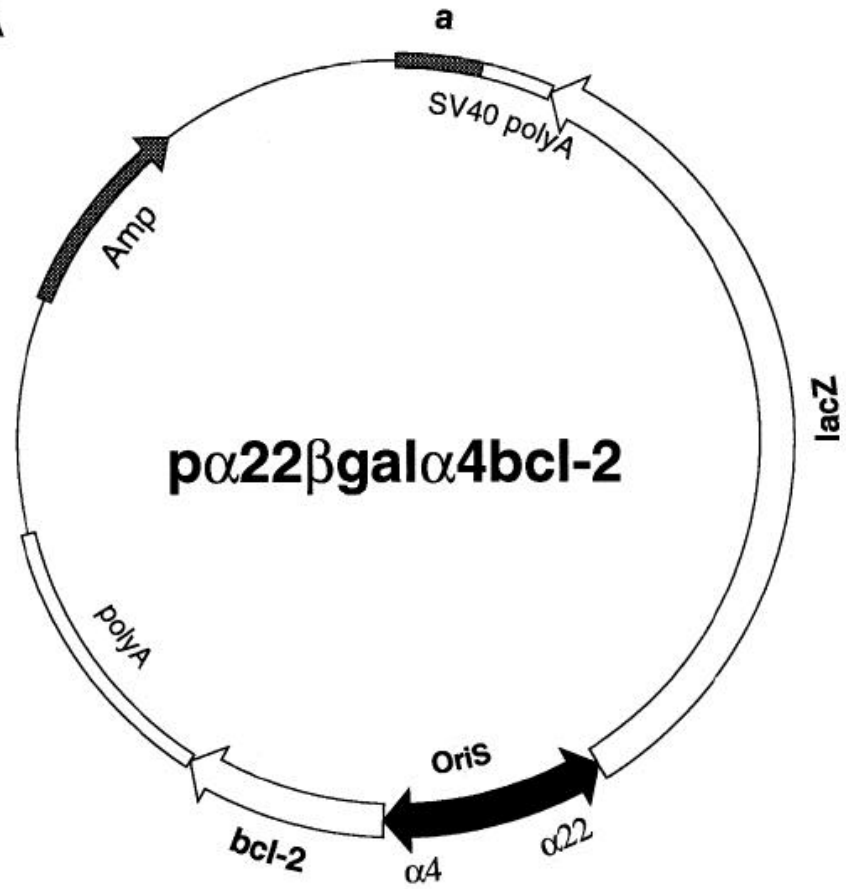

B

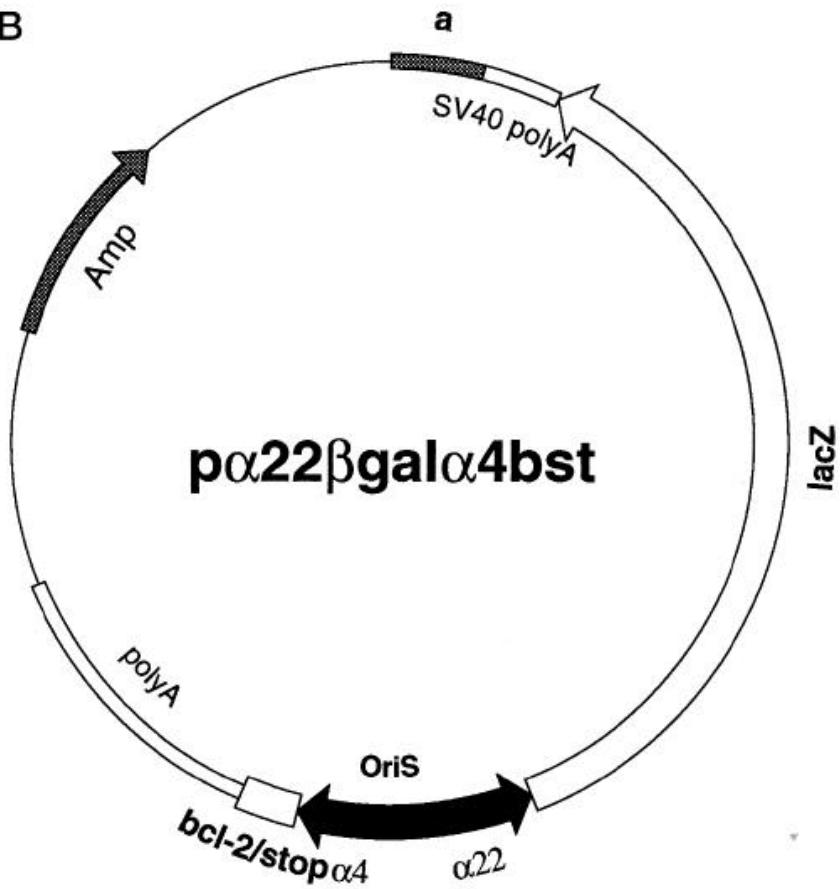

Figure 1. A, The structure of $\mathrm{p} \alpha 22 \beta \mathrm{gal} \alpha 4 \mathrm{bcl}-2$. The $b c l-2$ and $l a c Z$ transcriptional units are driven by the HSV $\alpha 4$ and $\alpha 22$ immediate-early promoters and terminated by unc-54 $3^{\prime}$ poly $A$ and $S V 40$ poly $A$ signals, respectively. The HSV $a$ sequence is included to provide the necessary packaging signal, and the HSV sequence that contains the $\alpha 4$ and $\alpha 22$ promoter contains the OriS necessary for replication. $B$, A similar control plasmid, p $\alpha 22 \beta \mathrm{gal} \alpha 4 \mathrm{bst}$, has a $560 \mathrm{bp}$ deletion and stop codons inserted in the $b c l-2$ sequence.

expressed as a percent of the number in the nonoccluded control hemisphere, and a comparison of survivorship between $\mathrm{Bcl}-2$ and control groups was performed by ANOVA. A comparison of the number of surviving neurons in the occluded hemispheres of each brain to their own contralateral controls within each group was made using a paired Student's $t$ test. Infarct damage was confirmed by the presence of clear lesions within the striatum and assigned a degree of severity on a scale of
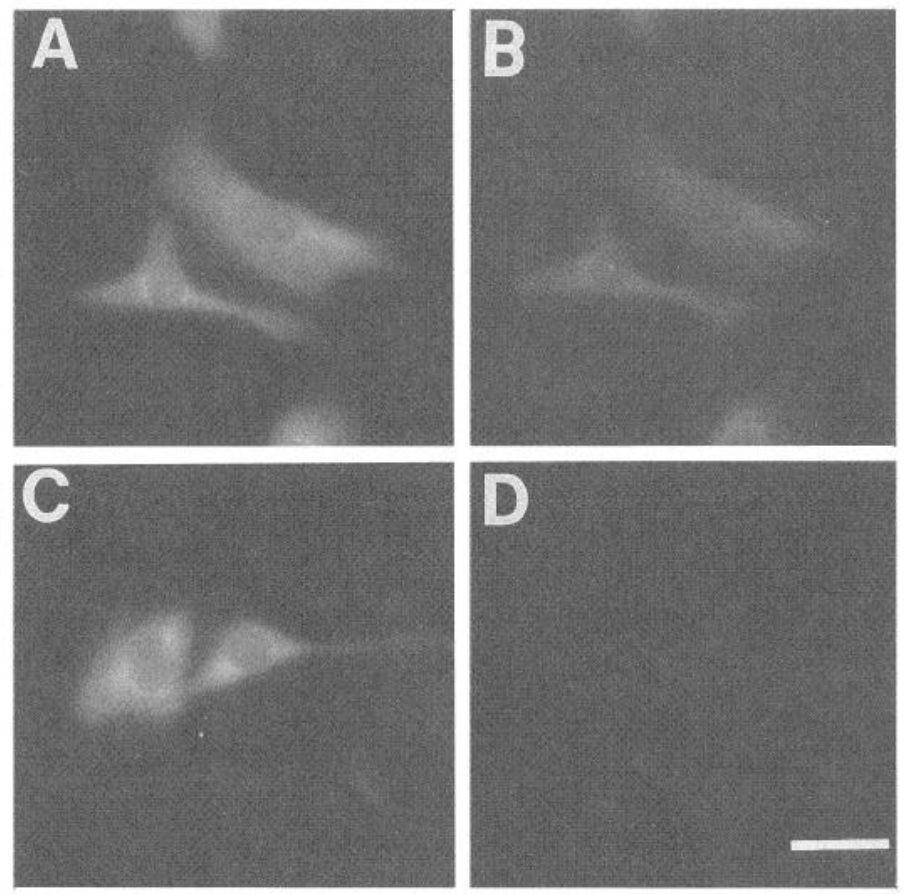

Figure 2. Double immunofluorescence of v $\alpha 22 \beta \mathrm{gal} \alpha 4 \mathrm{bcl}-2$-infected Vero cells revealed strong coexpression of $\beta$-gal $(A)$ and $\mathrm{Bcl}-2(B)$. v $\alpha 22 \beta$ galv $\alpha 4$ bst-Infected cells exhibited $\beta$-gal $(C)$ but not Bcl-2 $(D)$ expression. Scale bar $=25 \mu \mathrm{m}$.

0 to 5 , in which 0 represented no visible damage in the occluded hemisphere under $20 \times$ magnification and 5 represented complete ablation of the striatum and surrounding cortex. Those brains exhibiting 0 damage were not included in the analysis. A comparison of damage between $\mathrm{Bcl}-2$ and control groups was made using a nonparametric $\chi^{2}$ test.

\section{RESULTS}

\section{Expression of human bcl-2 in rat hippocampal neurons and Vero cells}

Viral vectors capable of delivering $b c l-2$ to postmitotic neurons were generated by using the replicative, packaging, and neurotrophic properties of HSV (Ho et al., 1993). A plasmid, designated p $\alpha 22 \beta$ gal $\alpha 4$ bcl-2, was constructed bearing the HSV origin of replication and packaging sequences and the human $b c l-2$ and $E$. coli lacZ genes under the control of the HSV $\alpha 4$ and $\alpha 22$ promoters, respectively (Fig. 1A). A control plasmid, designated p $\alpha 22 \beta$ gal $\alpha 4$ bst, was constructed containing a stop codon in the $b c l-2$ sequence, which resulted in the expression of an inactive truncated gene product (Fig. $1 B$ ). Vectors v $\alpha 22 \beta$ gal $\alpha 4$ bcl- 2 and v $\alpha 22 \beta$ gal $\alpha 4$ bst were generated from these plasmids. Vero cells infected with v $\alpha 22 \beta$ gal $\alpha 4 \mathrm{bcl}-2$ exhibited coexpression of both the $\beta$-gal and $\mathrm{Bcl}-2$ as demonstrated by immunofluorescence, whereas those infected with v $\alpha 22 \beta$ gal $\alpha 4$ bst only exhibited expression of $\beta$-gal (Fig. 2). In the quantification of the number of $\mathrm{Bcl}-2$ and $\beta$-gal ${ }^{+}$cells in v $\alpha 22 \beta$ gal $\alpha 4 \mathrm{bcl}-2$-infected Vero cells, it was found that $98.7 \pm 1.2 \%$ of the cells exhibited coexpression of the two gene products. Hippocampal neurons infected with v $\alpha 22 \beta \mathrm{gal} \alpha 4 \mathrm{bcl}-2$ in vivo also coexpressed Bcl-2 and $\beta$-gal (see Fig. 8).

\section{Bcl-2 expression protects against an oxidative insult in vitro}

To determine whether the overexpression of $\mathrm{Bcl}-2$ would protect hippocampal neurons against a known oxidative insult, we examined the viability of virally infected neurons after exposure to adriamycin. 

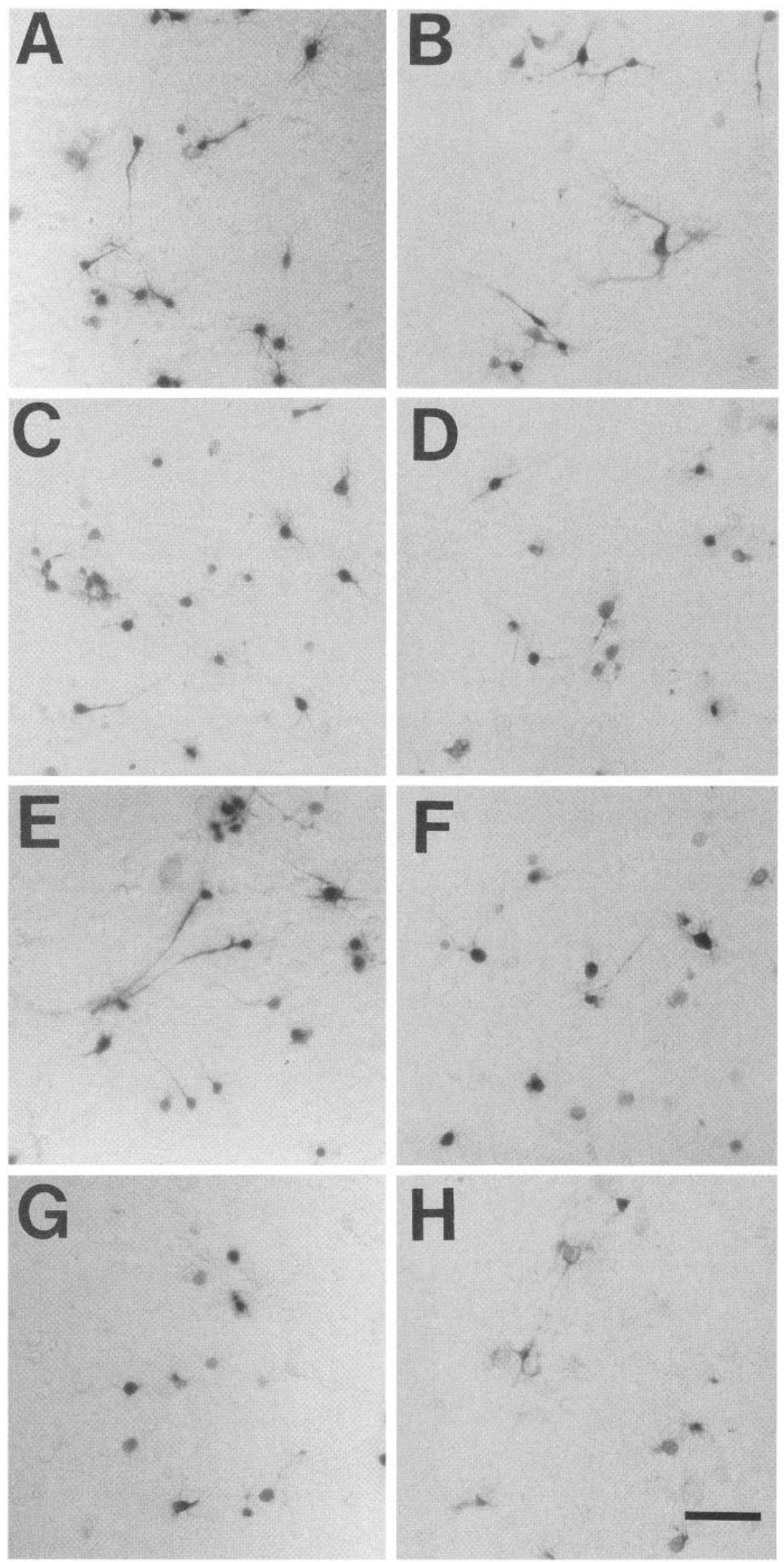

Figure 3. v $\alpha 22 \beta \mathrm{gal} \alpha 4 \mathrm{bcl}-2$-infected hippocampal cultures subjected to $0(A), 0.3(B), 2.7(C)$, and 24.3 $\mu \mathrm{M}(D)$ adriamycin for $24 \mathrm{hr}$. v $\alpha 22 \beta$ gal $\alpha 4$ bstinfected cultures subjected to the same adriamycin treatments $(E-H)$. Cells positive for X-gal are black. Those exhibiting intact processes were counted as healthy viable neurons. Note that at each dosage of adriamycin there are a greater number of healthy intact $\beta$-gal ${ }^{+}$neurons in the Bcl-2-infected cultures. Scale bar $=100 \mu \mathrm{m}$. 


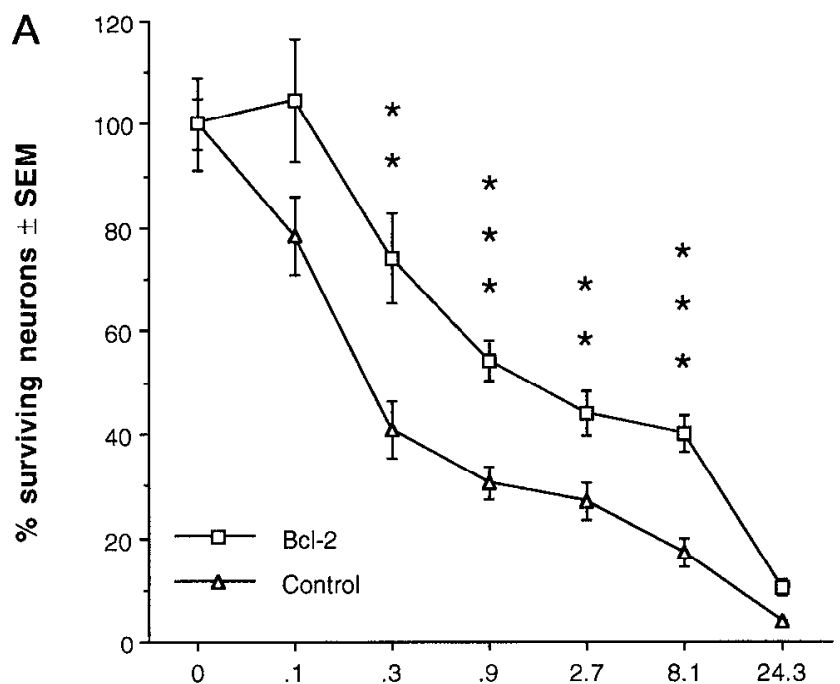

$\mu \mathrm{M}$ adriamycin

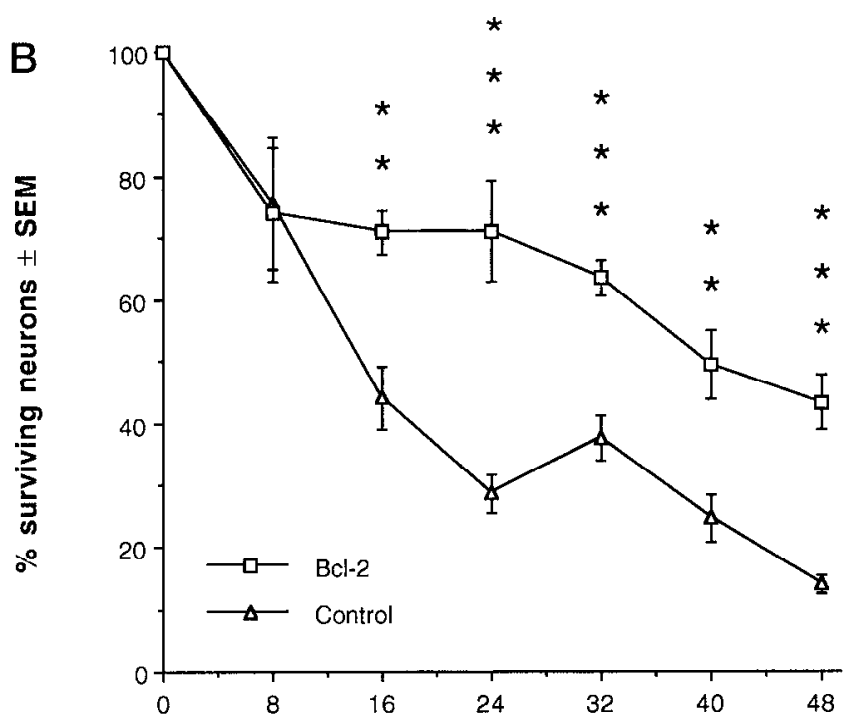

adriamycin exposure (hours)

Figure 4. A, Survivorship of v $\alpha 22 \beta \mathrm{gal} \alpha 4 \mathrm{bcl}-2$ - and $\mathrm{v} \alpha 22 \beta \mathrm{gal} \alpha 4 \mathrm{bst}$ infected cultured hippocampal neurons after a $24 \mathrm{hr}$ exposure to a range of adriamycin doses ( $n=18$ wells in each treatment). $B$, Survivorship after different durations of exposure to $0.9 \mu \mathrm{M}$ adriamycin $(n=6)$. ${ }^{*} p<0.05$; $*^{* *} p<0.01 ;{ }^{* * *} p<0.001$; Scheffe post-hoc test after two-way ANOVA comparing Bcl-2 and control at a given adriamycin concentration or time point.

This quinone-containing antitumor agent contributes to the intracellular accumulation of superoxide radicals by undergoing redox cycling within the microsomal electron transport chain (Halliwell and Gutteridge, 1989). When hippocampal cultures were infected with $\mathrm{Bcl}-2$ or control vectors before adriamycin treatment, Bcl-2 overexpression enhanced survivorship (Fig. 3), shifting the median lethal dose $\left(\mathrm{LD}_{50}\right)$ of adriamycin from $0.25 \mu \mathrm{M}$ in v $\alpha 22 \beta \mathrm{gal} \alpha 4 \mathrm{bst}-\mathrm{infected}$ neurons to $1.40 \mu \mathrm{M}$ in v $\alpha 22 \beta$ gal $\alpha 4 \mathrm{bcl}-2$-infected neurons (Fig. $4 A$ ). When cultures were infected before exposure to $0.9 \mu \mathrm{M}$ adriamycin for different durations, the mean time at which adriamycin caused $50 \%$ lethality was approximately doubled from $21.8 \mathrm{hr}$ in v $\alpha 22 \beta$ gal $\alpha 4$ bst-infected neurons to $41.3 \mathrm{hr}$ in $v \alpha 22 \beta \mathrm{gal} \alpha 4 \mathrm{bcl}-2$

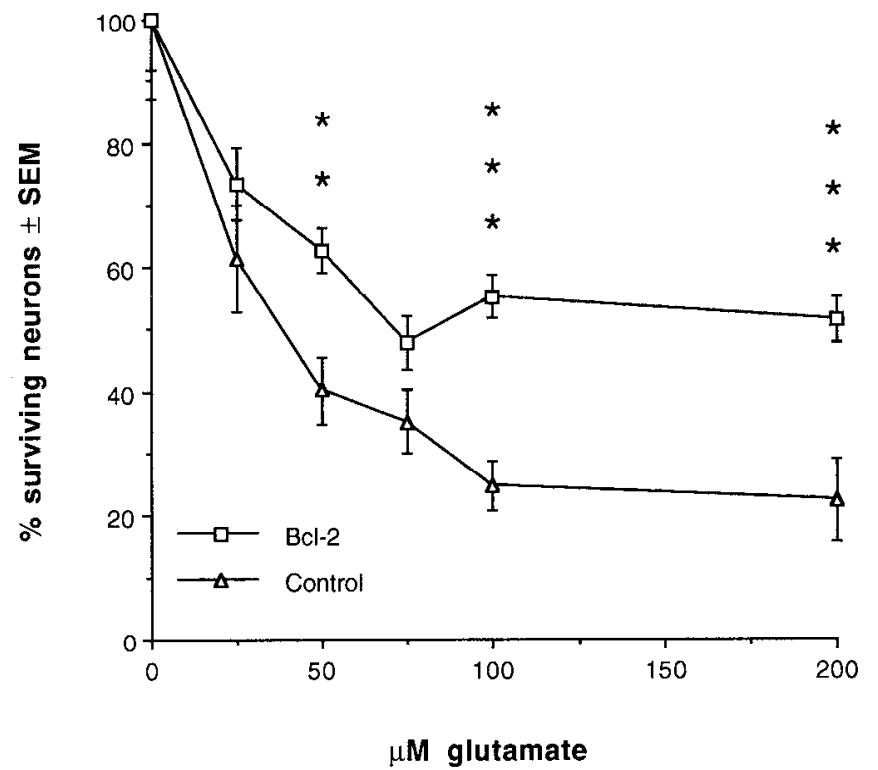

Figure 5. Survivorship of v $\alpha 22 \beta$ gal $\alpha 4$ bcl-2- and v $\alpha 22 \beta$ gal $\alpha 4$ bst-infecled cultured hippocampal neurons after a $30 \mathrm{~min}$ exposure to glutamate $(n=$ 16 in each treatment). ${ }^{*} p<0.05 ;{ }^{* *} p<0.01$; *** $<0.001$; Scheffe post-hoc test after two-way ANOVA comparing $\mathrm{Bcl}-2$ and control at a given glutamate concentration.

infected neurons (Fig. $4 B$ ). The application of the appropriate criteria for distinguishing between $\beta$-gal ${ }^{+}$neurons and glia was confirmed by costaining for $\beta$-gal and MAP2 immunoreactivity, which revealed that $\beta$-gal ${ }^{+}$cells exhibiting neuron-like morphologies were also positive for the neuron-specific MAP2 protein (data not shown).

\section{$\mathrm{Bcl}-2$ expression protects against an excitotoxic and hypoglycemic insult in vitro}

We evaluated whether v $\alpha 22 \beta \mathrm{gal} \alpha 4 \mathrm{bcl}-2$ would have similar protective effects against glutamate exposure. $\mathrm{Bcl}-2$ doubled the glutamate $\mathrm{LD}_{50}$ from $37 \mu \mathrm{M}$ in $v \alpha 22 \beta$ gal $\alpha 4$ bst-infected neurons to

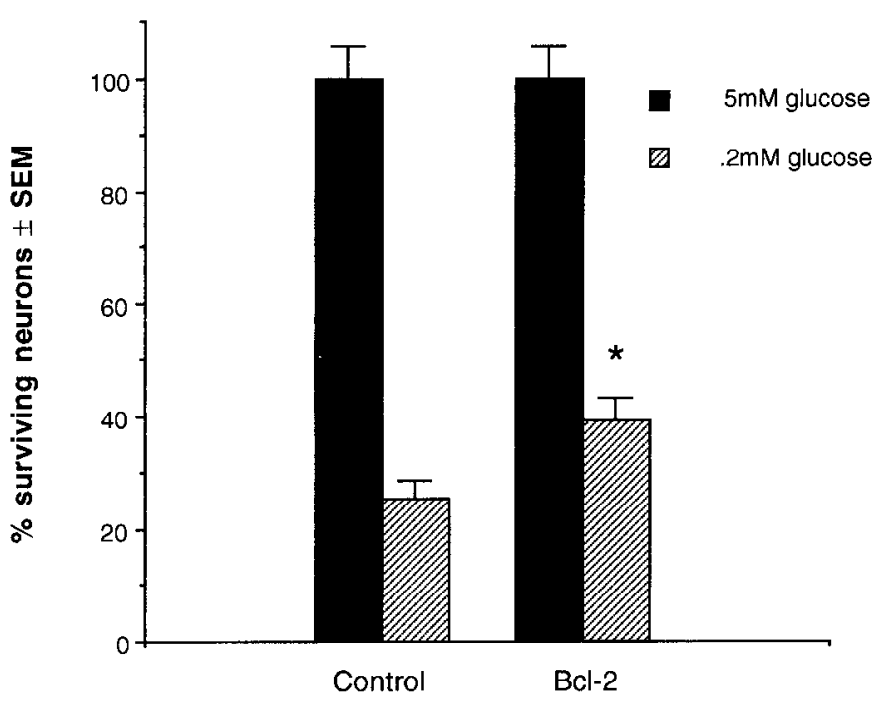

Figure 6. Survivorship of v $\alpha 22 \beta \mathrm{gal} \alpha 4 \mathrm{bcl}-2-$ and $v \alpha 22 \beta \mathrm{gal} \alpha 4 \mathrm{bst}-\mathrm{infected}$ cultured hippocampal neurons after exposure to hypoglycemia $(0.2 \mathrm{mM}$ glucose) expressed as a percentage of survivorship seen in control normoglycemic cultures ( $5 \mathrm{~mm}$ glucose) $\left(n=24\right.$ in each treatment). ${ }^{*} p=0.01$; Scheffe post-hoc test comparing Bcl-2 and control cultures under hypoglycemic conditions. 


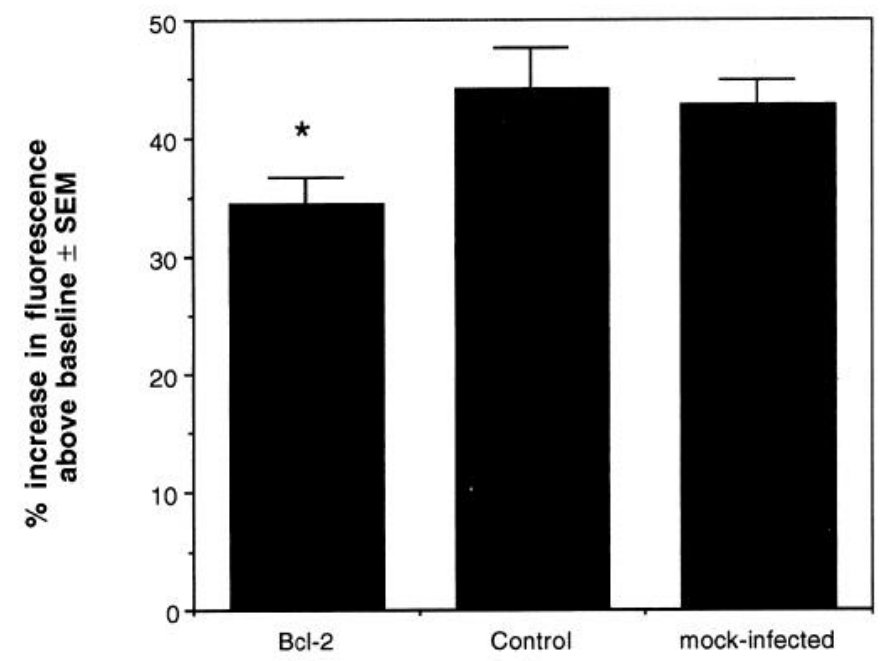

Figure 7. Oxygen radical species generation in hippocampal cultures infected with $v \alpha 22 \beta \mathrm{gal} \alpha 4 \mathrm{bcl}-2, v \alpha 22 \beta \mathrm{gal} \alpha 4 \mathrm{bst}$, or mock-infected as assessed by DCF fluorescence. Cultures were treated with $1 \mu \mathrm{M}$ adriamycin for $20 \mathrm{hr}$, and fluorescence values in each treatment group are expressed as the percent increase in fluorescence relative to control uninfected wells that had not been treated with adriamycin ( $n=60$ in each treatment). ${ }^{*} p$ $<0.05$; Fisher PLSD comparing Bcl-2, control vector, and mock-infected cultures.

$70 \mu \mathrm{M}$ in $v \alpha 22 \beta$ gal $\alpha 4 \mathrm{bcl}-2$-infected neurons (Fig. 5). Expression of Bcl-2 during a $24 \mathrm{hr}$ hypoglycemic insult also enhanced survivorship (Fig. 6).

\section{Bcl-2 prevents lipid peroxidation}

Because v $\alpha 22 \beta$ gal $\alpha 4 \mathrm{bcl}-2$ reduced the toxicity of a known oxygen radical generator, and of glutamate, which causes damage in part via the production of oxygen radicals, it was expected that the vector would also reduce the accumulation of oxygen radicals and peroxidative damage. This was observed, in that infection with v $\alpha 22 \beta$ gal $\alpha 4$ bcl- 2 , but not $v \alpha 22 \beta$ gal $\alpha 4$ bst, significantly reduced the amount of DCF fluorescence in mixed hippocampal cultures compared with uninfected controls after treatment with the prooxidant adriamycin (Fig. 7).

\section{Bcl-2 protects against an oxidative insult in vivo}

Adriamycin infusion into the hìppocampus causes lesions in the cell fields of the dentate and cornus ammons. Delivery of the vectors v $\alpha 22 \beta$ gal $\alpha 4 \mathrm{bcl}-2$ or v $\alpha 22 \beta$ gal $\alpha 4$ bst to the dorsal horn of the dentate gave rise to $\beta$-gal expression in dentate granular neurons (Fig. 9). v $\alpha 22 \beta$ gal $\alpha 4$ bcl-2-Infected neurons exhibited significantly enhanced survivorship relative to v $\alpha 22 \beta \mathrm{gal} \alpha 4 \mathrm{bst}-$ infected neurons when the vectors were delivered $12 \mathrm{hr}$ before adriamycin but not when delivered simultaneously with the insult (Fig. 10). An insufficient number of neurons was targeted with v $\alpha 22 \beta$ gal $\alpha 4 \mathrm{bcl}-2$ to actually reduce the size of the lesion induced in the dentate. In animals receiving v $\alpha 22 \beta$ gal $\alpha 4 \mathrm{bcl}-212 \mathrm{hr}$ before the insult, the total number of $\beta$-gal ${ }^{+}$neurons counted in the dentate was $155.8 \pm 11.6(n=7)$ in adriamycin-treated hemispheres and $145.8 \pm 13.7(n=11)$ in untreated hemispheres, whereas the total number in animals receiving $\mathrm{v} \alpha 22 \beta \mathrm{gal} \alpha 4$ bst was $69.7 \pm 11.4(n=10)$ and $122.6 \pm 11.6(n=13)$, respectively. Similar amounts of total adriamycin damage in $v \alpha 22 \beta$ gal $\alpha 4 \mathrm{bcl}-2$ and v $\alpha 22 \beta$ gal $\alpha 4$ bst-infected animals, however, indicate that the differential survivorship was not attributable to the degree of damage experienced by each group (the lesions induced in v $\alpha 22 \beta$ gal $\alpha 4 \mathrm{bcl}-2-$ and $v \alpha 22 \beta$ gal $\alpha 4$ bst-infected animals measured
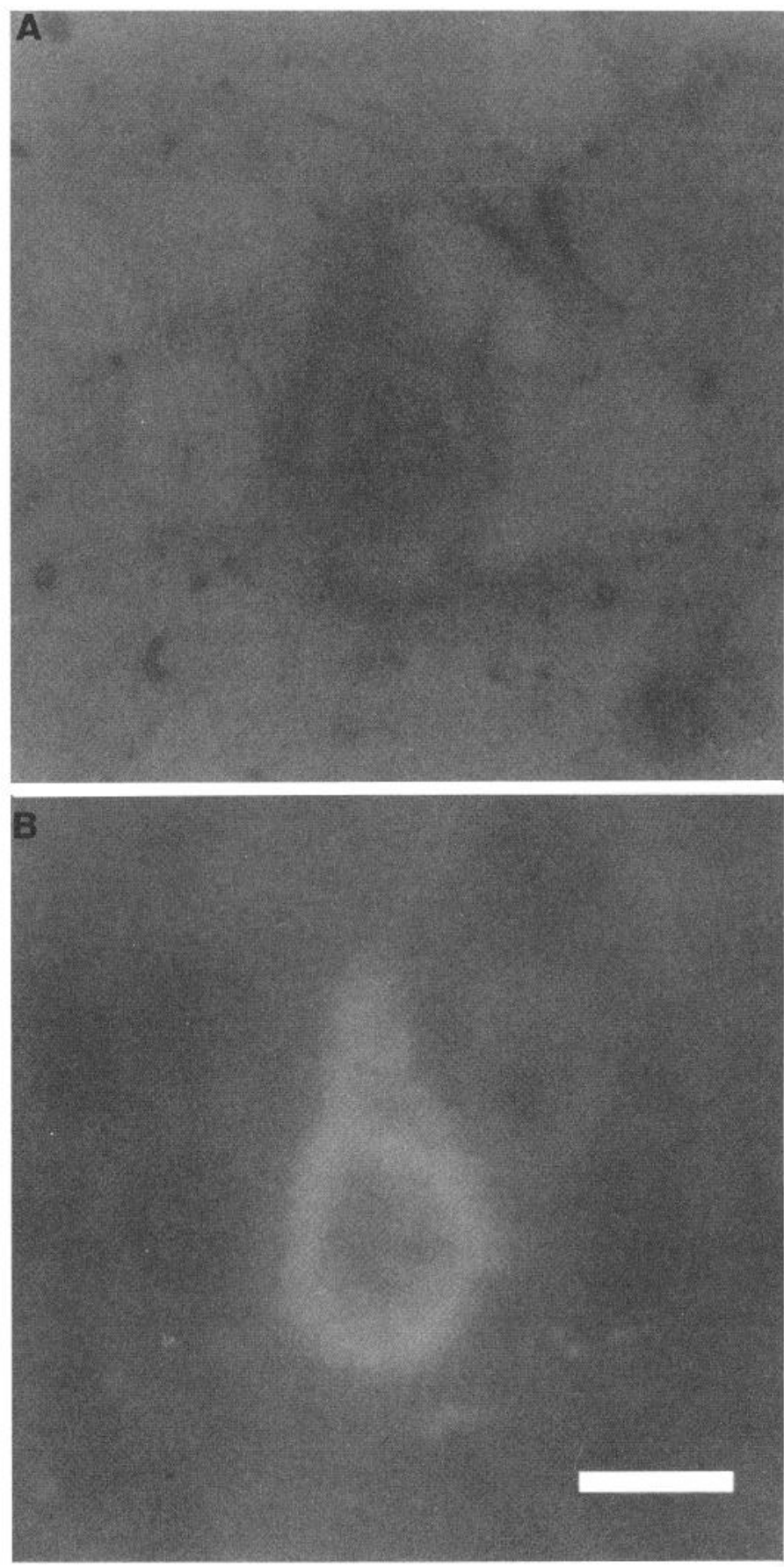

Figure 8. Double immunofluorescence of a $v \alpha 22 \beta \mathrm{gal} \alpha 4 \mathrm{bcl}-2$-infected dentate neuron demonstrates colocalization of $\operatorname{Bcl}-2(A)$ and $\beta$-gal $(B)$. Scale bar $=25 \mu \mathrm{m}$.

$44.29 \pm 10.45$ and $38.19 \pm 8.08 \mathrm{~mm}^{3}$, respectively; data not shown). A comparison of the titer of the infused vector stock and an estimate of the total number of successfully targeted neurons in nonoccluded control cell fields yielded an efficiency of infection of $\sim 5 \%$.

\section{$\mathrm{Bcl}-2$ protects against hypoxia-ischemia}

One hour occlusion of the middle cerebral artery caused a focal ischemic infarct within the medial and lateral striatum and, in some cases, the overlying cerebral cortex. The delivery of v $\alpha 22 \beta \mathrm{gal} \alpha 4 \mathrm{bcl}-2$ and $v \alpha 22 \beta$ gal $\alpha 4$ bst before the occlusion gave rise to expression of 

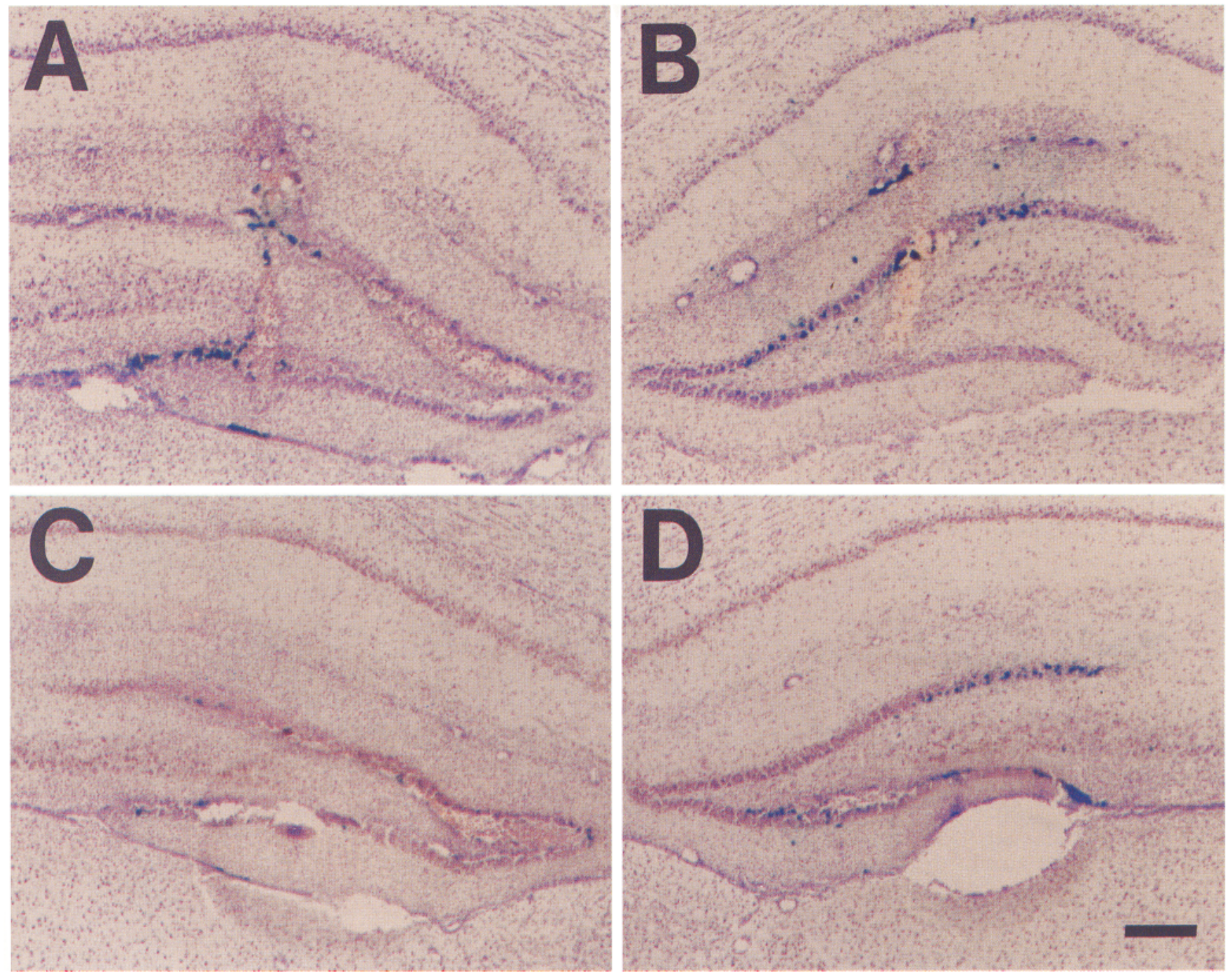

Figure 9. Representative photomicrographs of v $\alpha 22 \beta \mathrm{gal} \alpha 4 \mathrm{bcl}-2$ expression in a dentate gyrus that had received adriamycin $(A)$ and a contralateral cell field that had not received adriamycin $(B)$, and $v \alpha 22 \beta$ gal $\alpha 4$ bst expression under the same treatment conditions $(C, D)$. There is a slight difference in the amount of adriamycin-induced damage, as indicated by a greater overall number of neurons remaining in the damaged hemisphere of the v $\alpha 22 \beta \mathrm{gal} \alpha 4 \mathrm{bcl}-$ 2 -infected brain. More notable, however, is the difference in the number of $\beta$-gal ${ }^{+}$neurons in the two treatment groups. Scale bar $=250 \mu \mathrm{m}$.

$\beta$-gal in striatal neurons, some of which lay within the lesioned cell field (Fig. 11). $\beta$-gal ${ }^{+}$neurons were found within the occluded hemisphere of both Bcl-2 and control animals, but the number of such neurons surviving, when expressed as a percent of the number of positive neurons in the contralateral control hemisphere, was significantly greater in animals receiving v $\alpha 22 \beta$ gal $\alpha 4 \mathrm{bcl}-2$ than in animals receiving $v \alpha 22 \beta$ gal $\alpha 4$ bst (Table 1 ). Brains in the two groups, however, exhibited no significant difference in the amount of total ischemic damage within the region of infusion $(\mathrm{Bcl}-2$ damage $=2.90$ \pm 0.43 ; control damage $=2.91 \pm 0.39 ; \chi^{2}=0.152$; data not shown), indicating that the differential survivorship of $v \alpha 22 \beta \mathrm{gal} \alpha 4 \mathrm{bcl}-2-\mathrm{vs}$ $v \alpha 22 \beta$ gal $\alpha 4$ bst-infected neurons did not arise from the differing degrees of ischemia endured by animals in each group.

\section{DISCUSSION}

The use of vectors constructed from neurotrophic viruses such as HSV appears to be one of the few viable routes for the transfer of genes into postmitotic neurons, and the neuroprotective potential of such gene therapy strategies has been explored in a number of recent reports (During et al., 1994; Ho et al., 1995; Lawrence et al., 1995a). In the present investigation, we have extended this approach by generating HSV vectors bearing the human $b c l-2$ gene. We observe that these vectors protect both hippocampal and striatal neurons against a variety of necrotic insults. This finding is of heuristic value in that it gives further insight into both the mechanisms of Bcl-2 action and of the particular insults that it protects against. In addition, these results give further credence to the general potential of viral vectors for gene therapy in the CNS.

Short-term expression of Bcl-2 under the control of the $\alpha 4$ promoter conferred protection against oxidative, excitotoxic, and hypoglycemic stresses in both primary hippocampal cultures and the intact brain. The assumption that positive $\mathrm{X}$-gal staining in v $\alpha 22 \beta$ gal $\alpha 4$ bcl-2-infected neurons indicates Bcl- 2 overexpression is supported by our demonstration of the coexpression of $\mathrm{Bcl}-2$ and $\beta$-gal in hippocampal neurons by double immunofluorescence and is supported further by our demonstration of the consistent coexpression of gene products using this bicistronic system in both Vero cells and the striatum (Lawrence et al., 1995b). 


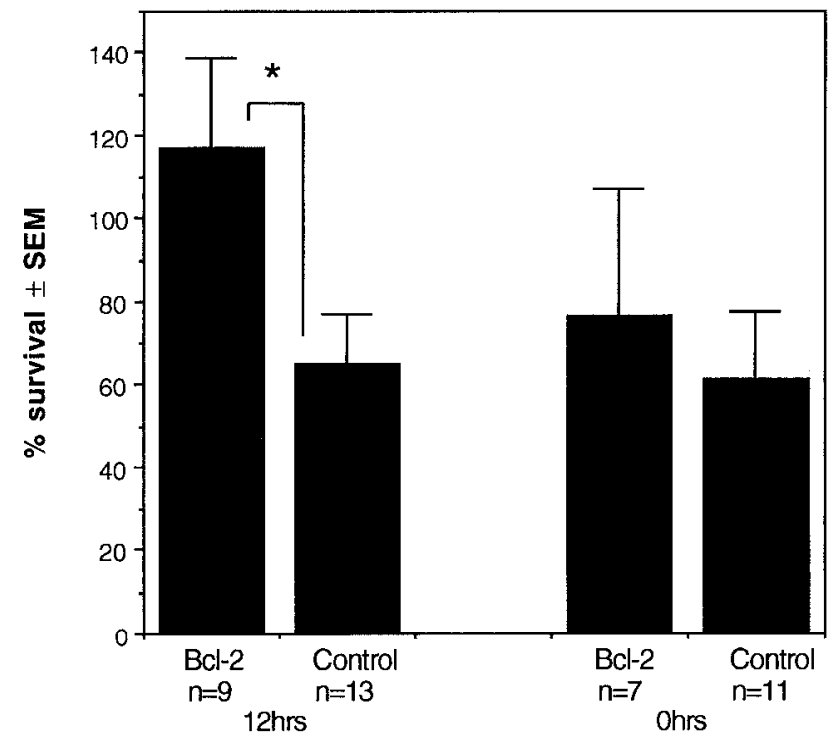

Figure 10. Survivorship of v $\alpha 22 \beta g a l \alpha 4 b c l-2$ - and v $\alpha 22 \beta$ gal $\alpha 4$ bst-infected dentate neurons when infected $12 \mathrm{hr}$ before (left) or simultaneous with (right) the delivery of adriamycin. Data are represented as the mean percent of $\beta$-gal-expressing neurons remaining in the adriamycin-treated hemisphere versus the contralateral control hemisphere. ${ }^{*} p<0.05$ by Scheffe post-hoc test after two-way ANOVA, comparing $\mathrm{Bcl}-2$ and control at the 12 hr mark.

The broad protective effect exhibited by Bcl-2 against many different insults and across many cell types (Behl et al., 1993; Kane et al., 1993; Zhong et al., 1993a,b) has been attributed to its ability to function as an antioxidant. Bcl-2 overexpression protects lymphocytic cells from $\mathrm{H}_{2} \mathrm{O}_{2}$ - and menadione-induced oxidative death and completely blocks the lipid peroxidation in these cells that occurs in association with apoptosis (Hockenbery et al., 1993). Bcl-2 has also been found to block the intracellular accumulation of reactive oxygen species and lipid peroxides that results from depletion of glutathione, an important cellular antioxidant (Kane et al., 1993). Our finding that infection with $v \alpha 22 \beta \mathrm{gal} \alpha 4 \mathrm{bcl}-2$ reduced the amount of DCF fluorescence in hippocampal cultures after adriamycin exposure suggests that $\mathrm{Bcl}-2$ can function in this antioxidant capacity in CNS neurons. Although the antioxidant role of $\mathrm{Bcl}-2$ has been supported by many studies, this is not true of all reports (Jacobson and Raff, 1995; Shimizu et al., 1995). A possible, but less well supported, neuroprotective mechanism may involve antiproteolytic activities (Yuan et al., 1993).

The demonstration that $\mathrm{Bcl}-2$ may prevent cell death by reducing the accumulation of reactive oxygen species, in turn, suggests that there is a significant oxygen radical component to the insults that it protects against. This is most clearly the case for protection against adriamycin, an anthracycline with a quinone-containing tetracyclic ring structure, which has a potent capacity to generate free oxygen radicals (Halliwell and Gutteridge, 1989). Although the antitumor properties of adriamycin have been attributed to its ability to intercalate between DNA base pairs, adriamycin derivatives that do not bind to DNA maintain their antitumor effectiveness (Halliwell and Gutteridge, 1989). Thus, adriamycin's celldamaging effects (against either tumor cells or neurons) appear to arise principally through the generation of oxygen radicals. Our finding that the in vivo delivery of v $\alpha 22 \beta \mathrm{gal} \alpha 4 \mathrm{bcl}-212 \mathrm{hr}$ before, but not simultaneous with, the administration of adriamycin was protective suggests that the oxidative damage induced by adria- mycin occurs within the time necessary for the production of sufficient amounts of Bcl-2 to be protective.

Bcl 2's ability to protect against glutamate is consistent with the abundant evidence implicating oxidative stress in excitotoxic neuron death (Coyle and Puttfarcken, 1993). Glutamatergic excitation through NMDA receptors stimulates phospholipase A2 activity and the subsequent release of arachidonic acid and generation of oxygen radicals (Dumuis et al., 1988), including superoxide (Lafon-Cazal et al., 1993), the accumulation of which depletes the endogenous antioxidant glutathione (Murphy et al., 1990). To the extent that the depletion of neuronal energy supplies has a direct effect on a neuron's ability to maintain reduced glutathione stores and other important endogenous antioxidants, hypoglycemia also represents an oxidative stress (Saez et al., 1987). The relatively limited protection observed against hypoglycemia, compared with that seen against adriamycin and glutamate (compare Figs. 4 and 5 with Fig. 6), may reflect the relative greater importance of other aspects of energetic endangerment with hypoglycemia, such as the failure to maintain ion homeostasis.

The oxidative nature of hypoxic-ischemic injury is indicated by the accumulation of conjugated dienes and thiobarbituric acidreactive materials, both of which signify lipid peroxidation (Yoshida et al., 1980; Halliwell and Gutteridge, 1989), and is supported further by the demonstration that antioxidants such as catalase and supcroxide dismutase protect against ischemic damage (Liu et al., 1989). Our report that the expression of exogenous Bcl-2 in individual neurons enhances survivorship after focal ischemia agrees with a previous finding that transgenic mice overexpressing $\mathrm{Bcl}-2$ exhibit reduced infarct damage after middle cerebral artery occlusion (Martinou et al., 1994), and agrees with a recent abstract reporting a similar protective effect of an HSV vector expressing Bcl-2 in the ral cortex (Linnik el al., 1994).

Physiologically, Bcl-2's immortalizing effects and its differential expression in different cell lineages are important in the regulation of hematopoietic cell survival and, hence, lymphoid development (Reed, 1994). Bcl-2's wide expression in the neonatal brain suggests a similar role in the regulation of the apoptosis during brain development (Merry et al., 1994). Whether Bcl-2 continues to function as a regulator of either apoptosis or necrotic cell death in the mature brain, where its expression is less pronounced, remains unclear. Neurological insults may induce the expression of endogenous $\mathrm{Bcl}-2$ as an adaptive strategy to thwart delayed neuron death, as suggested by the fact that the induction of tolerance to ischemia in the CA1 of the hippocampus by a transient ischemic event is associated with increased endogenous Bcl-2 immunoreactivity (Shimazaki et al., 1994). Bcl-2's continued high expression in the mature peripheral nervous system also suggests that it plays an important role in promoting the survival and maintaining the regenerative potential of these neurons (Merry et al., 1994). Our results demonstrate that Bcl-2 can function in such a protective capacity if it is expressed in the mature CNS.

Besides giving insight as to the mechanisms of Bcl-2 action and the possible oxidative component to various necrotic insults, these findings add to the list of HSV-derived vectors shown to have some neuroprotective properties. One promising feature of this approach derives from the speed of expression of these vectors compared with the time course of delayed neuron death. Genes placed under the control of the HSV $\alpha 4$ promoter express within $4 \mathrm{hr}$ and achieve a maximal level of expression within $8 \mathrm{hr}$, which is sustained over a $48-72 \mathrm{hr}$ period. Thus, delivery of 


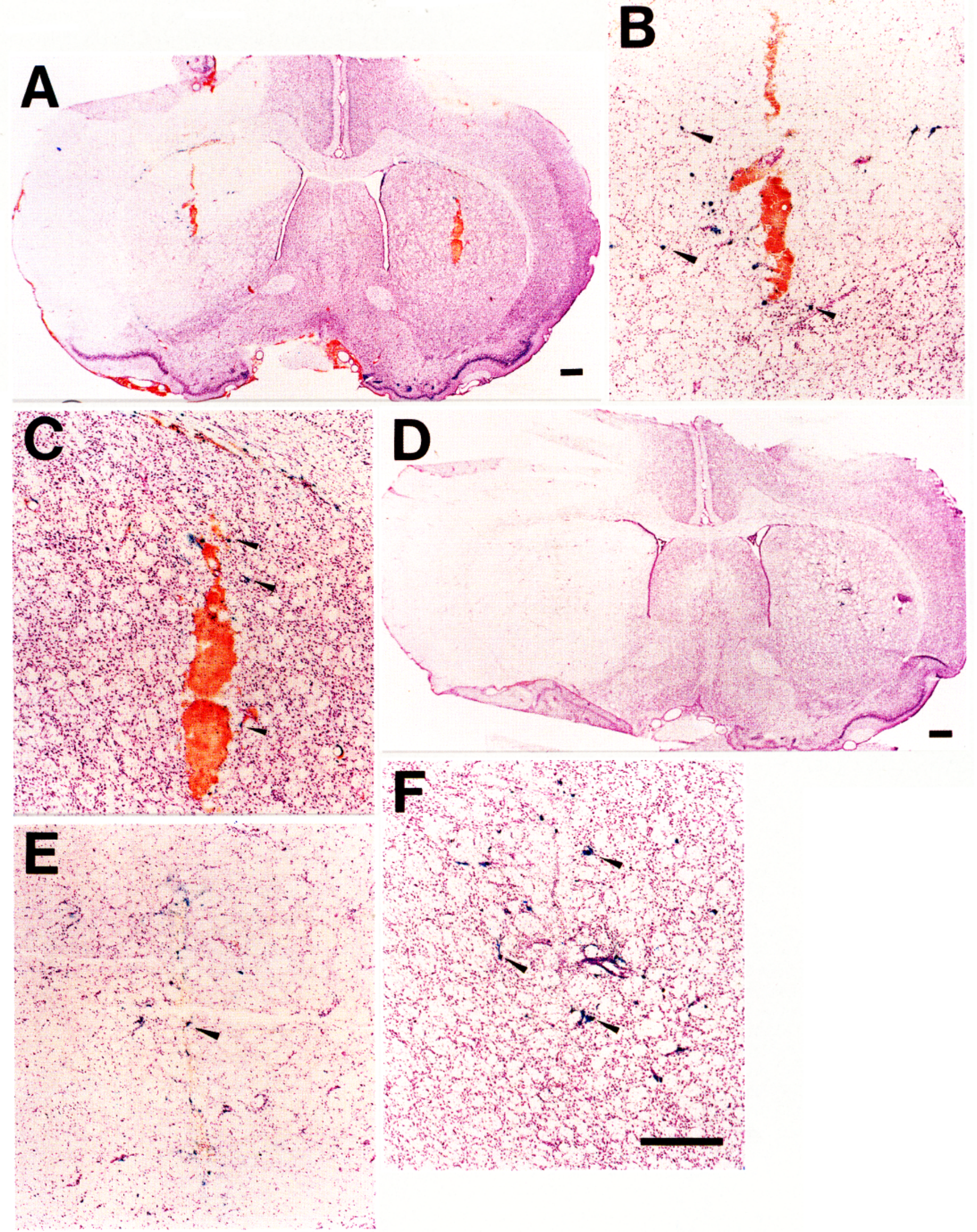


Table 1. Survivorship of v $\alpha 22 \beta$ gal $\alpha 4 \mathrm{bcl}-2-$ and v $\alpha 22 \beta$ gal $\alpha 4 \mathrm{bst}$-infected striatal neurons in animals subjected to MCAO

\begin{tabular}{lllll} 
& $\begin{array}{l}\text { No. surviving } \\
\text { neurons in } \\
\text { occluded } \\
\text { hemisphere }\end{array}$ & $\begin{array}{l}\text { No. surviving } \\
\text { neurons in } \\
\text { control } \\
\text { hemisphere }\end{array}$ & $\begin{array}{l}\text { Survival } \\
(\%)\end{array}$ & $n$ \\
\hline Bcl 2 & $87.3 \pm 19.9$ & $81.7 \pm 12.5$ & $107.2 \pm 17.0$ & 10 \\
Control & $68.2 \pm 17.8$ & $118 \pm 26.2$ & $64.2 \pm 10.5$ & 11
\end{tabular}

Relative survival is represented as the mean percent of $\beta$-gal-expressing neurons remaining in the occluded hemisphere versus the contralateral unoccluded hemisphere. Differences in neuron survivorship between Bcl-2 and control groups were significant $(p<0.05$ by a Scheffe post-hoc test). Differences in the total number of neurons between occluded and unoccluded hemispheres within each group were significant in control animals ( $p<0.05$, paired student's $t$ test) but not in Bcl-2 animals.

v $\alpha 22 \beta$ gal $\alpha 4$ bcl-2 $6 \mathrm{hr}$ before a $1 \mathrm{hr}$ occlusion of the middle cerebral artery resulted in $\mathrm{Bcl}-2$ expression during the ischemic event and subsequent reperfusion period and contributed to neuron survival. The delayed nature of necrotic neuron death and the efficacy of postinsult pharmacological interventions such as the delivery of NMDA receptor antagonists (Levy and Lipton, 1990) suggest that delivery of $v \alpha 22 \beta \mathrm{gal} \alpha 4 \mathrm{bcl}-2$ at the time of the focal ischemia or immediately afterward is also protective. In support of this idea, we have observed that an HSV-derived vector overexpressing the glucose transporter gene can protect against seizure and a metabolic toxin in the rat hippocampus, even when delivered up to 1 hr after the insult (Lawrence et al., 1995a; Dash et al., 1995).

Because of the low efficiencies of infection and the titers of the viral innoculums used, only a small portion of the striatal or hippocampal neuron populations overexpressed $\mathrm{Bcl}-2$ in animals subjected to focal ischemia or adriamycin-induced oxidative damage. This precluded complete protection against some of the insult models, and there was no reduction in the overall extent of the lesions induced. Along with the invasive route of delivery, the inclusion of potentially disruptive helper virus and the confined and local extent of expression represent limitations in the use of such viral vectors at present. However, our findings, along with the other recent reports cited, suggest that as these technical limitations are circumvented, HSV. vectors and other evolving viral vector strategies offer a promising means of delivering novel neuroprotective genes to the CNS.

\section{REFERENCES}

Allsopp TE, Wyatt S, Paterson HF, Davies AM (1993) The protooncogene $b c l-2$ can selectively rescue neurotrophic factor-dependent neurons from apoptosis. Cell 73:295-307.

Bakhshi A, Jensen JP, Goldman P, Wright JJ, McBride OW, Epstein AL, Korsmeyer SJ (1985) Cloning the chromosomal breakpoint of $t(14 ; 18)$ human lymphomas: clustering around $\mathrm{JH}$ on chromosome 14 and near a transcriptional unit on 18. Cell 41:889-906.

Behl C, Hovey L, Krajewski S, Schubert D, Reed JC (1993) Bcl-2 prevents killing of neuronal cells by glutamate but not by amyloid $\beta$ protein. Biochem Biophys Res Commun 197:949-956.

Coyle J, Puttfarcken P (1993) Oxidative stress, glutamate, and neurodegenerative disorders. Science 262:689-695.
Dash R, Lawrence M, Ho D, Sapolsky R (1995) A herpes simplex virus vector overexpressing the glucose transporter gene protects the rat dentate gyrus from an antimetabolite toxin. Exp Neurol, in press.

DeLuca NA, McCarthy AM, Schaffer PA (1985) Isolation and characterization of deletion mutants of herpes simplex virus type 1 in the gene incoding immediate-early regulatory protein ICP4. I Virol 56:558-570.

Dubois-Dauphin M, Frankowski H, Tsujimoto Y, Huarte J, Martinou JC (1994) Neonatal motor neurons overexpressing the $b c l$-2 protooncogene in transgenic mice arc protected from axotomy-induced cell death. Proc Natl Acad Sci USA 91:3309-3313.

Dumuis A, Sebben M, Haynes H, Pin JP, Bockaert J (1988) NMDA receptors activate the arachidonic acid cascade system in striatal neurons. Nature 336:68-72.

During MJ, Naegele JR, O'Malley KL, Geller AI (1994) Long-term behavioral recovery in Parkinsonian rats by an HSV vector expressing tyrosine hydroxylase. Science 266:1399-1403.

Garcia I, Martinnu I, Tsujimoto Y, Martinou JC (1992) Prevention of programmed cell death of sympathetic neurons by the $b c l-2$ protooncogene. Science 258:302-304.

Halliwell B, Guttcridge. JMC (1989) Frec radicals in biology and mcdicine. New York: Oxford UP.

Ho DY, Mocarski ES, Sapolsky RM (1993) Altering central nervous system physiology with a defective herpes simplex virus vector expressing the glucose transporter gene. Proc Natl Acad Sci USA 90:3655-3659.

Ho, DY (1994) Amplicon-based herpes simplex virus vectors. Methods Cell Biol 43:191-210.

Ho DY, Saydem TC, Fink SI, I awrence MS, Sapolsky RM (1995) Defective herpes simplex virus vectors expressing the rat brain glucose transporter protect cultured neurons from necrotic insults. J Neurochcm 65:842-848.

Hockenbery D, Nunez G, Milliman C, Schreiber RD, Korsmeyer SJ (1990) $\mathrm{Bcl}-2$ is an innermitochondrial membrane protein that blocks programmed cell death. Nature 348:334-336.

Hockenbery DM, Oltvai ZN, Yin XM, Milliman CL, Korsmeyer SJ (1993) Bcl-2 functions in an antioxidant pathway to prevent apoptosis. Cell 75:241-251.

Hockenbery DM, Zutter M, Hickey W, Nahm M, Korsmeyer SJ (1991) $\mathrm{Bcl}-2$ protein is topographically restricted in tissues characterized by apoptotic cell death. Proc Natl Acad Sci USA 88:6961-6965.

Jacobson MD, Raff MC (1995) Programmed cell death and Bcl-2 protection in very low oxygen. Nature $374: 814-816$.

Kane DJ, Sarafian TA, Anton R, Hahn H, Gralla EB, Valentine JS, Ord $T$, Bredesen DE (1993) Bcl-2 inhibition of neural death: decreased generation of reactive oxygen species. Science 262:1274-1277.

Lafon-Cazal M, Pietre S, Culasi M, Bockaert J (1993) NMDAdependent superoxide production and neurotoxicity. Nature 364:535-537.

Lawrence MS, Dash R, Ho DY, Sapolsky RM (1995a) Herpes simplex virus vectors overexpressing the glucose transporter gene protect against seizure-induced neuron loss. Proc Natl Acad Sci USA 92:7247-7251.

Lawrence MS, Sun GI, Kunis DM, Saydem TC, Dash R, IIo DY, Sapolsky RM, Steinberg GK (1995b) Overexpression of the glucose transporter gene with a herpes simplex viral vector protects striatal neurons against stroke. J Cereb Blood Flow Metab, in press.

Lebel CP, Ali SF, McKee M, Bondy SC (1990) Organometal-induced increase in oxygen reactive species: the potential of dichlorofluorescein diacitate as an index of neurotoxic damage. Toxicol Appl Pharmacol $104: 17-25$.

I evy DI, I ipton SA (1990) Comparison of delayed administration of competitive and uncompetitive antagonists in preventing NMDA receptor-mediated neuronal death. Neurology 40:852-855.

Linnik MD, Zahos P, Geschwind MD, Federoff HJ (1994) Expression of Bcl-2 from a defective herpes simplex virus limits neuronal death in stroke. Soc Neurosci Abstr 609:8.

Figure 11. Representative photomicrographs of striatal sections from an animal that had been infected with v $\alpha 22 \beta \mathrm{gal} \alpha 4 \mathrm{bcl}-2$ reveal the extent of middle cerebral artery occlusion damage in the left hemisphere $(A)$ and, at a higher magnification, the number of lac $Z^{+}$neurons (several indicated by arrows) in the lesioned $(B)$ and control $(C)$ hemispheres. A similar sequenec of photomicrographs of the pattern of cxpression and survivorship in v $\alpha 22 \beta$ gal $\alpha 4$ bstinfected striatal neurons reveals significantly fewer $\beta$-gal ${ }^{+}$neurons remaining in the ischemic hemisphere $(D-F)$. The total number of such neurons counted over successive sections allowed a measure of neuron survival. Scale bar $=500 \mu \mathrm{m}$. 
Lithgow T, van Driel R, Bertram JF, Strasser A (1994) The protein product of the oncogene $b c l-2$ is a component of the nuclear envelope, the endoplasmic reticulum, and the outer mitochondrial membrane. Cell Growth Differ 5:411-417.

Liu TH, Beckman JS, Freeman BA, Hogan EL, Hsu CY (1989) Polyethylene glycoconjugated superoxide dismutase and catalase reduce ischemic brain injury. Am J Physiol 256:H589-H593.

Longa EZ, Weinstein PR, Carlson S, Cummins R (1989) Reversible middle cerebral artery occlusion without craniectomy in rats. Stroke 20:84-91.

Mah SP, Zhong LT, Liu Y, Roghani A, Edwards RH, Bredesen DE (1993) The protooncogene bcl-2 inhibits apoptosis in PC12 cells. J Neurochem 60:1183-1186.

Martinou, JC, Dubois-Dauphin M, Staple JK, Rodriguez I, Frankowski H, Missutten M, Albertini P, Talabot D, Catsicas S, Pietra C, Huarte J (1994) Overexpression of Bcl-2 in transgenic mice protects neurons from naturally occurring cell death and experimental ischemia. Neuron 13:1017-1030.

Memezawa H, Minamisawa H, Smith ML, Siesjo BK (1992) Ischemic penumbra in a model of reversible middle cerebral artery occlusion in the rat. Exp Brain Res 89:67-78.

Merry DE, Veis DJ, Hickey WF, Korsmeyer SJ (1994) Bcl-2 protein expression is widepread in the developing nervous system and retained in the adult PNS. Development 120:301-311.

Murphy TH, Schnaar RL, Coyle JT (1990) Immature cotical neurons are uniquely sensitive to glutamate toxicity by inhibition of cystine uptakc. FASEB J 3:1624-1633.

Nunez G, London L, Hockenbery D, Alexander M, McKearn JP, Korsmeyer SJ (1990) Deregulated Bcl-2 gene expression selectively prolongs survival of growth factor-deprived hemopoietic cell lines. J Immunol 144:3602-3610.

Reed JC (1994) Bcl-2 and the regulation of programmed cell death. J Cell Biol 124:1-6.

Rosenkranz AR, Schmaldienst S, Stuhlmeier KM, Chen W, Knapp W, Zlabinger GJ (1992) A microplate assay for the detection of oxidative products using $2^{\prime}, 7^{\prime}$-dichlorofluorescein-diacetate. J Immunol Methods 156:39-45.

Saez J, Kessler J, Bennett M, Spray D (1987) Superoxide dismutase protects cultured neurons against death by starvation. Proc Natl Acad Sci US $\Lambda$ 84:3056 3060 .
Sentman CL, Shutter JR, Hockenbery D, Kanagawa O, Korsmeyer SJ (1991) Bcl-2 inhibits multiple forms of apoptosis but not negative selection in thymocytes. Cell 67:879-888.

Shimazaki K, Ishida A, Kawai N (1994) Increase in Bcl-2 oncoprotein and the tolerance to ischemia-induced neuronal death in the gerbil hippocampus. Neurosci Res 20:95-99.

Shimizu S, Eguchi Y, Kosaka H, Kamiike W, Matsuda H, Tsujimoto Y (1995) Prevention of hypoxia-induced cell death by Bcl-2 and Bcl-xL. Nature 374:811-813.

Strasser A, Harris AW, Cory S (1991) Bcl-2 transgene inhibits T cell death and perturbs thymic self-censorship. Cell 67:889-899.

Tombaugh G, Yang S, Swanson R, Sapolsky R (1992) Glucocorticoids exacerbate hypoxic and hypoglycemic hippocampal injury in vitro: biochemical correlates and a role for astrocytes. J Neurochem 59:137-146.

Tsujimoto Y, Gorham J, Cossam J, Jaffe E, Croce C (1985) The t(14;18) chromosome translocations involved in B-cell neoplasms result from mistakes in VDJ joining. Science 229:1300-1303.

Vaux DL (1988) Bcl-2 gene promotes haemopoietic cell survival and cooperates with c-myc to immortalize pre-B cells. Nature 335:440-442.

Vaux DL, Weissman IL, Kim SK (1992) Prevention of programmed cell death in Ceanorhabditis elegans by human bcl-2. Science 258:1955-1957.

Wood KA, Youle RJ (1994) Apoptosis and free radicals. In: The neurobiology of $\mathrm{NO}$. and ' $\mathrm{OH}$ (Chiuch $\mathrm{CC}$, Gilbert DL, Colton, $\mathrm{CA}$, cds), pp 400-407. New York: New York Academy of Sciences.

Yoon EJ, Steinberg GK (1994) Mild intraischemic hypothermia protects against focal cerebral ischemia. Soc Neurosci Abstr 19:225.

Yoshida S, Inoh S, Asano T (1980) Effect of transient ischemia on free fatty acids and phospholipids in the gerbil brain: lipid peroxidation as a possible cause of post ischemic injury. J Neurosurg 53:323-331.

Yuan J, Shaham S, Ledoux S, Ellis HM, Horvitz HR (1993) The C. elegans cell death gene ced-3 encodes a protein similar to mammalian interleukin-1 $\beta$-converting enzyme. Cell 75:641-652.

Zhong LT, Kane DJ, Bredesen DE (1993a) Bcl-2 blocks glutamate toxicity in neuronal cell lines. Mol Brain Res 19:353-355.

Zhong LT, Sarafian T, Kane DJ, Charles AC, Mah SP, Edwards RH, Bredesen DE (1993b) Bcl-2 inhibits death of central neural cells induced by multiple agents. Proc Natl Acad Sci USA 90:4533-4537. 